\title{
ERRORS ANALYSIS OF THE SENTENCES MADE BY FRESHMEN OF ENGLISH DEPARTMENT
}

\author{
Wiwiet Eva Savitri \\ Email:wiwieteva@unesa.ac.id \\ Suvi Akhiriyah \\ Email:suviakhiriyah@unesa.ac.id \\ State University of Surabaya
}

\begin{abstract}
Writing sentence is not a simple task. Yet, it is found many times that even students of latest semesters are unable to compose good writing text due to their inability in producing good sentences. It is an unfortunate because ability in writing good sentences is the fundamental for the next level of writing. The failure of senior students to make good sentences triggers questions on what materials to focus on and how to conduct teaching and learning in the writing and grammar classes. In line with those, this study tries to reveal the errors freshmen students usually make in writing sentences. It is expected that the result of this study helps lecturers to choose appropriate materials and teaching techniques. The results of this study show that most errors are found in terms of grammar, mechanic, logic, and spelling. Hence, it is suggested that freshmen practice sentence writing more to practice the grammar rules, spelling, and mechanic as well as to sharpen their ability in building logical sentences.
\end{abstract}

Keywords: writing, error, grammar, logic

\section{INTRODUCTION}

English is a language which is used by many people in global communication. In Indonesia, English is the only foreign language taught generally at schools all around in Indonesia. Therefore, being able to master the four skills of English is the common expectation the students have whenever they learn English. Being able to communicate fluently in English is the highest expectation people have on the students. The expectation is higher on students of English department.

Beside able in speaking English fluently, students who study in English Department in any universities are expected to be able to write well. Writing skill helps university students a lot in doing assignments 
which are in essay forms. Students will feel the need of writing ability more when their time to do their thesis comes. In line with this, Bjork and Raisanen (1997, p. 8) state that writing is essential because writing is a thinking tool for language development, for critical thinking, andfor learning in all disciplines. Thus, as one of the active or productive skills of language usage, writing skill in English is significant in students' academic life. This skill helps students in taking notes, answering written questions, writing reports, and writing essays.Bacha (2002, p. 164) states that the process of writinghelps to develop the students' cognitive skills in acquiring the necessary strategies such as analyzing results of a research task.

However, making good writing product is not an easy task to accomplish. It is not easy to express idea using own sentences. As a result, there are many students who abuse internet. In the era of internet nowadays, it is easy for students to access and get sources from internet. Some are tempted to simply copy all the things they get from internet and paste them to their work. What they do is plagiarism. It is a shameful conduct in academic world. Besides, it is a crime.

To avoid plagiarism, students should be proud of their own piece of writing. Although, as stated previously, it is not easy to produce good written work, they must realize that their own words are valuable. In making their final written project or thesis, students need to be able to express the ideas they have in mind properly. They need to produce grammatically correct and logically acceptable sentences. It is essential to avoid misunderstanding. They also need to express their ideas in convincing paragraphs in which unity, cohesion, and coherence are important parts. Yet, it is a fact that many senior students do not know how to express their ideas in proper sentences. There are still many errors found in senior students' writing. It is proved in preliminary observation made on the research proposal made by students of 2012 and 2013. There are many of them who still make sentence level errors due to their inability to apply grammar rules properly. Interviews with the students indicate that they do not realize that they produce unacceptable sentences. Their errors might be fossilized already. 
Error Analysis (EA) is concerned with the analyses of the errors made by the learners of a target language by comparing the norms that the learners have acquired with norms ofthe target language (James, 1998). It also explains the identified errors.In Second Language Acquisition, EA was established by Corder and his colleaguesin the 1970s. They stated that EA is a type of linguistic study that focuses on the errors learners make.According to Corder (1967), EA has theoretical and applied objects. The theoretical object is to understand what and how a learner learns when he studies an second language (L2). The applied object is to enable the learner to learn more efficiently by using the knowledge of his dialect for pedagogical purposes. At the same time, the investigation of errors can serve two purposes, diagnostic and prognostic. According to Corder, errors are valuable because it give clues for teachers on the progress of the students; it provides researchers with evidence on how language is acquired or learned; it gives learners resources to learn.

James (2001) stated that EA refers to the study of linguistic ignorance. This investiges what people do not know and how they attempt to cope with it. Brown (2000, p. 224) defines EA as the process to observe, analyze, and classify the misuse of the rules and to reveal the systems operated by learner. Interlingual errors and intralingual errors are the two main sources of errors. Interlingual errors are also referred as interference errors. These are the type of errors which are traceable to first language interference. These errors deals with negative interlingual transfer. The term interlingual was first introduced by Selinker (1972). He used this term to refer to the systematic knowledge of a target language which is independent of both the learner's native language and the target language. Intralingual errors view errors as the result of partial learning of the target language rather than language transfer (Keshavarz, 2003; Fang and Jiang, 2007).

Researchers who are interested in error analysis claim that errors are beneficial for both learners and teachers. It provides information to the teachers on students' errors so that it helps the teachers to correct the errors, to improve their teaching, and to focus onareas that need reinforcement (Al-haysoni, 2012). Related to the 
kind of errors that are committed by students, Ridha (2012) found that most serious and frequent errors committed by learners are the grammatical errors and the mechanical errors.

Weireesh (1991) views EA as a valuable aid to identify and explain difficulties faced by learners. He believes that EA plays a role as a reliable feedback to design a teaching method, especially the remedial one. Moreover, EA helps to reveal the level of language proficiency the learner has reached, to obtain information about common difficulties in language learning, and to find out how people learn a language (Sercombe, 2000).

Some researchers believe that making errors is unavoidable. Olasehinde (2002)is an example of those who states that errors are unavoidable and a necessary part of the learning curve. Stark (2001) explains that errors should be viewed positively and should not be regarded as inability to understand rules and structures. It should be viewed as a part of learning process.

It is normal that learners make errors. The most important thing to do is to help the students to be aware of the errors they make themselves and eventually to be able to correct the errors. However, it is unfortunate if senior students are not able to free themselves from errors. Especially, the errors made are still found in sentence level, in terms of grammar, mechanic, and logic.

Efforts to reduce sentence level errors are essential to make. The efforts should be applied to the juniors with the hope that in the future when they have to write their paper or thesis they will not face similar problems in making sentences. One of the efforts is to find out the common errors made by freshmen of English Department. By knowing the common errors earlier, it is expected that lecturers can help the students to identify and correct them so that the students will not make more or the same sentence level errors. Knowing the common errors will also help the institution in organizing the subjects which deal with the teaching of grammar. It will help a lot in the material selection. Based on the reasoning above, it is believed that a study to reveal the common errors made by freshmen of Unesa English Department needs to be conducted. 


\section{METHODS}

This is a descriptive qualitative research. The subjects of this research are freshmen of Unesa English Department year 2016. Freshmen are taken as the subject because this research tries to reveal the errors commonly made by them so that lecturers will be able to help them to correct and minimize the errors earlier. In order to get the data, the freshmen writing samples are taken. The samples of the students' writing provide sentences produced by the freshmen. They were taken from students' writing pretest and early semester assignments. To select the participants of the present study, a simple random sampling method was used. This is used because it is considered reliable to obtain a representative sample.

It is assumed that their writing that time is not much influenced by any teaching processes they have undergone in University. The sentences collected were then observed, classified, and analyzed descriptively. Since the samples are only from freshmen of 2016 in Unesa English Department, the result of this research cannot be generalized to the freshmen of other departments or universities.

\section{FINDINGS}

The sample sentences obtained for this study reveals that in general, freshmen of Unesa English Department produce most errors in terms of grammar, mechanic, logic, and spelling. The grammar errors committed by the students itself can be classified into11 groups. They are related to verb tense, verb-ing/infinitive, auxiliaries, word order, many/much, parallel structure, part of speech, modals, preposition, subject-verb agreement, and singular/plural. They are elaborated as follow

\section{Verb tense}

In term of verb tense usage, there are quite many sentences which indicate the students' shallow understanding on tenses rules. The examples below show the inappropriate use of simple present tense and simple past tense. It indicates that the students do not actually understand the patterns and, more importantly, the function of the tenses. 


\begin{tabular}{|l|l|}
\hline \multicolumn{1}{|c|}{ Error Identification } & \multicolumn{2}{|c|}{ Error Correction } \\
\hline $\begin{array}{l}\text { 1. The Chia-chia tribe learning } \\
\text { how to read, write, and } \\
\text { pronounce Hangul to save } \\
\text { their language. }\end{array}$ & $\begin{array}{l}\text { 1. The Chia-chia tribe learns } \\
\text { how to read, write, and } \\
\text { pronounce Hangul to save } \\
\text { their language. }\end{array}$ \\
$\begin{array}{l}\text { 2. In 2010, a team ask people } \\
\begin{array}{l}\text { around the world to film } \\
\text { their life on a single day. }\end{array}\end{array}$ & $\begin{array}{l}\text { 2. In 2010, a team asked people } \\
\text { around the world to film } \\
\text { their life on a single day. }\end{array}$ \\
\hline
\end{tabular}

\section{Verb-ing and/or infinitive}

The first grammar error which is found is the inappropriate use of verbs. Students tend to use v-ing after another verb such as want to. Some of them miss the verb which should be used after the previous one.

\begin{tabular}{|l|l|}
\hline \multicolumn{1}{|c|}{ Error Identification } & \multicolumn{2}{|c|}{ Error Correction } \\
\hline $\begin{array}{l}\text { 1. I want to traveling with my } \\
\text { family. }\end{array}$ & $\begin{array}{l}\text { 1. I want to travel with my } \\
\text { family. }\end{array}$ \\
$\begin{array}{l}\text { 2. I want taste all. } \\
\text { 3. I need to } \varnothing \text { an international } \\
\text { speech certificate. }\end{array}$ & $\begin{array}{l}\text { 2. I nant to taste all. } \\
\text { international to get an speech } \\
\text { certificate. }\end{array}$ \\
\hline
\end{tabular}

\section{Auxiliaries}

Most students are not aware of the importance used of auxiliaries especially in making questions. They are also not aware that the verb must be adjusted when auxiliaries are used.

\begin{tabular}{|l|l|}
\hline \multicolumn{1}{|c|}{ Error Identification } & \multicolumn{2}{|c|}{ Error Correction } \\
\hline $\begin{array}{l}\text { 1. When } \emptyset \text { the people gathered } \\
\text { an Arena Street Festival? }\end{array}$ & $\begin{array}{l}\text { 1. When did the people } \\
\text { gather an Arena Street } \\
\text { Festival? }\end{array}$ \\
$\begin{array}{l}\text { 2. What Kevin Macdonald did in } \\
2010 ?\end{array}$ & $\begin{array}{l}\text { 2. What did Kevin } \\
\text { Macdonald do in 2010? }\end{array}$ \\
\hline
\end{tabular}




\section{Word order}

Indonesian word order pattern seems to influence the way the students arrange their English sentence. It can be found especially when they use adjectives. Many students tend to put an adjective(s) after a noun, just like the rule of word order applied in Indonesian language. Here are the examples:

\begin{tabular}{|l|l|}
\hline \multicolumn{1}{|c|}{ Error Identification } & \multicolumn{1}{|c|}{ Error Correction } \\
\hline $\begin{array}{l}\text { 1. I want to have good score and } \\
\text { GPA stable. }\end{array}$ & $\begin{array}{l}\text { 1. I want to have good score } \\
\text { and stable GPA. }\end{array}$ \\
$\begin{array}{l}\text { 2. I need to study hard Korea } \\
\text { language. }\end{array}$ & $\begin{array}{l}\text { 2. I need to study Korea } \\
\text { language hard. }\end{array}$ \\
\hline
\end{tabular}

\section{Many/much}

\begin{tabular}{|l|l|}
\hline \multicolumn{1}{|c|}{ Error Identification } & \multicolumn{1}{|c|}{ Error Correction } \\
\hline $\begin{array}{l}\text { 1. How much people gave DNA } \\
\text { sampels in Astoria? }\end{array}$ & $\begin{array}{l}\text { 1. How many people gave } \\
\text { DNA sampels in Astoria? }\end{array}$ \\
$\begin{array}{l}\text { 2. Many student lazy to read } \\
\text { book. }\end{array}$ & $\begin{array}{l}\text { 2. Many students are lazy to } \\
\text { read book. }\end{array}$ \\
\hline
\end{tabular}

\section{Parallel structure}

\begin{tabular}{|l|l|}
\hline \multicolumn{1}{|c|}{ Error Identification } & \multicolumn{1}{|c|}{ Error Correction } \\
\hline $\begin{array}{l}\text { 1. Spencer Wells stopped and } \\
\text { talk people in Astoria. }\end{array}$ & $\begin{array}{l}\text { 1. Spencer Wells stopped } \\
\text { and talked to people in } \\
\text { Astoria. }\end{array}$ \\
$\begin{array}{l}\text { 2. Many people in rural region } \\
\text { can't read and writing well. }\end{array}$ & $\begin{array}{l}\text { 2. Many people in rural } \\
\text { region can't read and } \\
\text { write well. }\end{array}$ \\
\hline
\end{tabular}

\section{Part of speech}

It is found that many of the freshmen are still confused and cannot distinguish part of speech. Their problem related to understanding the function of the part of speech and the features that attributed part of speech. 


\begin{tabular}{|l|l|}
\hline Error Identification & \multicolumn{1}{|c|}{ Error Correction } \\
\hline 1. I need to be an activist person. & 1. I need to be an activist. \\
$\begin{array}{l}\text { 2. I want to learn Mandarin } \\
\begin{array}{l}\text { because it's a interest } \\
\text { language. }\end{array}\end{array}$ & $\begin{array}{l}\text { 2. I want to learn Mandarin } \\
\text { because it's an interesting } \\
\text { language. }\end{array}$ \\
\hline
\end{tabular}

\section{Modals}

Students' problems with modal are mostly about the use of to after a modal word. The use of to after modal words like can, must, may, might, and should still appears in the freshmen' sentences. On the contrary, they often forgot to put to after the modal be able. Another problem is the confusion of modal rules and simple present tense rules. The examples are shown as follow:

\begin{tabular}{|c|c|}
\hline Error Identification & Error Correction \\
\hline $\begin{array}{l}\text { 1. I want to be able speak } \\
\text { English, get a nice job from } \\
\text { that, and share my skill to other } \\
\text { people. }\end{array}$ & $\begin{array}{l}\text { 1. I want to be able to speak } \\
\text { English, get a nice job from } \\
\text { that, and share my skill to } \\
\text { other people. }\end{array}$ \\
\hline $\begin{array}{l}\text { 2. What can makes retracing the } \\
\text { past challenging? }\end{array}$ & $\begin{array}{l}\text { 2. What can make retracing } \\
\text { the past challenging? }\end{array}$ \\
\hline
\end{tabular}

\section{Preposition}

\begin{tabular}{|l|l|}
\hline \multicolumn{1}{|c|}{ Error Identification } & \multicolumn{1}{|c|}{ Error Correction } \\
\hline $\begin{array}{l}\text { 1. In my country has many kinds } \\
\text { of food. }\end{array}$ & $\begin{array}{l}\text { 1. } \begin{array}{l}\text { My country has many } \\
\text { kinds of food. }\end{array} \\
\begin{array}{l}\text { 2. Spencer Wells asked to people } \\
\text { in Astoria. }\end{array}\end{array} \begin{array}{l}\text { 2. Spencer Wells asked } \\
\text { people in Astoria. }\end{array}$ \\
\hline
\end{tabular}

\section{Subject-verb agreement and 11. singular/plural}

These two aspects are discussed simultaneously due to the fact that they often appear in the same time. Students who lack of knowledge on singular/plural tend to make errors related to subject-verb agreement. The examples are shown in the following table. 


\begin{tabular}{|l|l|}
\hline \multicolumn{1}{|c|}{ Error Identification } & \multicolumn{1}{|c|}{ Error Correction } \\
\hline $\begin{array}{l}\text { 1. Most students in my senior high } \\
\text { school is boy. }\end{array}$ & $\begin{array}{l}\text { Most students in my senior } \\
\text { high school were boys. }\end{array}$ \\
2. We should plant more tree. & $\begin{array}{l}\text { 2. We should plant more } \\
\text { trees. }\end{array}$ \\
\hline
\end{tabular}

Beside grammar errors, the freshmen also make obvious mechanic errors. Many of them are not aware on the use of capital letters, comma, and full stop. It causes run on sentences. The examples of the errors are shown in the following table.

\begin{tabular}{|l|l|}
\hline Error Identification & \multicolumn{1}{|c|}{ Error Correction } \\
\hline 1. I would send a video of my \\
$\begin{array}{l}\text { happiness when I and all my } \\
\text { family gather in one room. } \\
\text { Because I really miss them right } \\
\text { now, I miss their laugh, their } \\
\text { cry, and their behavior. }\end{array}$ & $\begin{array}{l}\text { I would send a video of my } \\
\text { my family gather in one } \\
\text { room because I really miss } \\
\text { them right now. I miss } \\
\text { their laugh, their cry, and } \\
\text { their behavior. }\end{array}$ \\
$\begin{array}{ll}\text { 2. I want to have an English course } \\
\text { and be a lecturer I need to } \\
\text { study hard, save the money, } \\
\text { have a special skill, and be a } \\
\text { good student } \emptyset\end{array}$ & $\begin{array}{l}\text { I want to have an English } \\
\text { need to study hard, save } \\
\text { the money, have a special } \\
\text { skill, and be a good } \\
\text { student. }\end{array}$ \\
\hline
\end{tabular}

After identifying these errors in the first week of the semester, the students have actually been told to be more aware of the errors. However, after some weeks of the lesson, such mechanic errors were still found in their writing. In order to avoid the error, they need reminder whenever they are asked to do writing task.

Beside grammar and logic errors, another obvious error committed by the freshmen is the ones related to sentence logic. The way the express their ideas often lead reader to grab meanings which are different from what they actually mean. They also get difficulty to 
give logical supporting ideas to emphasize their actual ideas. The examples are as follow.

\begin{tabular}{|l|l|}
\hline \multicolumn{1}{|c|}{ Error Identification } & \multicolumn{2}{|c|}{ Error Correction } \\
\hline $\begin{array}{l}\text { 1. We should reduce the air } \\
\text { pollution by planting mangrove } \\
\text { in the beach. }\end{array}$ & $\begin{array}{l}\text { 1. We should reduce } \\
\text { the air pollution by } \\
\text { planting more trees in } \\
\text { more areas. }\end{array}$ \\
2. What is your educational \\
goal? \\
$\begin{array}{l}\text { I want to improve myself so I will } \\
\text { get a satisfaction. }\end{array}$ & $\begin{array}{l}\text { I What is your } \\
\text { myself so I will be able } \\
\text { to speak and write in } \\
\text { English eloquently. }\end{array}$ \\
\hline
\end{tabular}

The other error committed by the freshmen is the spelling error. Many of them are unable to spell words correctly and need to consult dictionary to convince themselves. The examples of the errors are as follow.

\begin{tabular}{|l|l|}
\hline \multicolumn{1}{|c|}{ Error Identification } & \multicolumn{1}{|c|}{ Error Correction } \\
\hline $\begin{array}{l}\text { 1. I need to develop my leadership } \\
\text { skill, then increase my score in } \\
\text { my collage. }\end{array}$ & $\begin{array}{l}\text { I. need to develop my } \\
\text { leadership skill, then } \\
\text { increase my score in my } \\
\text { college. }\end{array}$ \\
$\begin{array}{l}\text { 2. I need to be a successfull } \\
\text { woman. }\end{array}$ & $\begin{array}{l}\text { 2. I need to be a successful } \\
\text { woman. }\end{array}$ \\
\hline
\end{tabular}

Those two examples are the examples of the most common spelling mistake found in this study. The suffix $-f u l$ is also an intriguing one for students. Many students still use - full instead of the correct form $-f u l$. This finding indicates that students need to be made aware on the suffixes and the word formation.

\section{CONCLUSION}

The errors found in this study are found in terms of grammar, mechanic, logic, and spelling. The grammar errors found can be classified into 11 groups. They are related to verb tense, verb- 
ing/infinitive, auxiliaries, word order, many/much, parallel structure, part of speech, modals, preposition, subject-verb agreement, and singular/plural. The mechanic errors mostly committed because of students' ignorance on the appropriate use of capital letters, comma, and full stop. Next, spelling error occurred only in few words, but they are committed by quite many students. The most spelling error occurred in the use of suffix -ful. Related to the logic error, the background knowledge of the students is the one to be questioned. It seems that they could not make logical sentences simply because they are not familiar with the topic.

Based on the findings above, it is suggested that freshmen practice sentence writing more to apply what they have learned related to grammar rules, spelling, and mechanic. It is also essential for the freshmen to deepen their understanding on the function of each grammar rules. Feedback from lecturers is also an essential part of the effort to reduce students' errors. Without feedback, it would be hard for the students to recognize the errors they make and enable themselves to make the correct ones. Peer editing practices need to be applied as well as to establish their awareness towards errors and their ability to identify and revise the erroneous sentences. Due to the students' schemata, literacy program could be a good way to sharpen their ability in building logical sentences. Yet, it is recommended that the application of the suggested solution be studied in the next researches to reveal whether they are actually able to reduce errors in students' writing.

\section{REFERENCES}

Bacha, N.N. (2002).Developing Learners' Academic Writing Skills in Higher Education: A Study for Educational Reform.Language \&Education vol. 16, issue 3.

Alhaisoni, M. (2012). An Analysis of Article Errors among Saudi Female EFL Students: A Case Study. Asian Social Science-Canadian Center of Science and Educationvol. 8, no 12.

Bjork, L and Raisanen, C. (1997). Academic Writing: A University Writing Course. Lund: Student literature. 
Brown ,H.(2000). Principles of Language Learning and Teaching. New Jersey: Prentice-Hall Inc.

Corder, S. (1967). TheSignificance of Learners' Errors.International Review of Applied Linguistics vol 5 no 4.

Fang, X and Jiang X.(2007). Error Analysis and the EFL Classroom Teaching.US- China Education Review vol 4, no 9.

James, C. (1988). Errors in Language Learning Use: Exploring Error Analysis. Harlow, Essex: Addison Wesley Longman Limited.

James, C. (2001).Errors in Language Learning Use: Exploring Error Analysis. Beijing: Foreign Language Teaching and Research Press.

Keshavarz, M. (2003). Error Analysis and Contrastive Analysis. Error Analysis in Translation and Learner Translation Corpora.

Olasehinde, M. O. (2002). Error Analysis and Remedial Pedagogy. In Babatunde S. T. and D. S. Adeyanju (eds.). Language, meaning and society. Ilorin: Itaytee Press and Publishing Co., Nigeria.

Ridha, N. (2012). The Effect of EFL Learners' Mother Tongue on their Writings in English: An Error Analysis Study. Journal of the College of Arts. University of Basrah.

Selinker, L. (1972). Interlanguage. International Review of Applied Linguistics in Language Teachingvol 10 issue 1-4. 